\title{
Development of a Remote Laboratory Infrastructure and LMS for Mechatronics Distance Education
}

\author{
Ayça Ak ${ }^{1 *}$, Vedat Topuz ${ }^{1}$, Aysun Altıkardeş ${ }^{1}$, Bekir Oral ${ }^{1}$ \\ ${ }^{1}$ Marmara University, Vocational School of Technical Sciences, Istanbul, TURKEY \\ Received 1 November 2017 • Revised 7 March 2018 • Accepted 26 March 2018
}

\begin{abstract}
The problem in schools with mechatronics programs is not only their low student capacity but also their theoretical-content-dominated curricula. However, the manufacturing industry needs highly-talented technical personnel with a lot of practice in this field. E-Learning Education for Mechatronics Remote Laboratory, EDUMEC, offers practical-content-dominated courses over the Internet. The situations and expectations of the target groups were designated using surveys to constitute the educational concepts for the e-mechatronics program and experiments. The target groups are students in vocational schools or engineering classes; engineers or technicians who have completed formal education in mechanical engineering, electrical/electronic engineering, or other technical fields; employers; and teachers. For training, a special multi-lingual e-learning platform has been built in a user-friendly environment with a Learning Management System (LMS). This paper presents the design and implementation of the remote laboratory and LMS. In addition, evaluations by the students who participated in the training are presented.
\end{abstract}

Keywords: e-learning, mechatronics, online education, remote laboratory

\section{INTRODUCTION}

The term "mechatronics" was popularized as technical terminology by a Japanese company, Yaskawa Electric Corporation, and since 1971, it has been protected as a trade name. In the early period of its use, mechatronics was understood as the design and construction activities concerning the inclusion of electronics and systems to the functional structure of various precision mechanisms. Mechatronics is an approach to engineering design that integrates mechanical, electrical and electronic, and computer engineering for a wide range of products and processes.

High-quality mechatronics education is important because there is a clear correlation between a company's economic power and the promotion and development of its junior staff. To be able to persist in global competition, a company requires a well-educated workforce. Engineers must be able to work in interdisciplinary teams, which generally have a multi-cultural composition, and may even be located in distributed places. Specifically, workers must know integrated methodology and design of not only products but also projects and processes. This shift away from traditional work and organizational models toward teamwork and inter-disciplinary projects requires an opposite consideration and response in the form of education (Welp, Labenda, \& Jansen, 2006).

A major goal of mechatronics education is to instill students with theoretical operational knowledge as well as practical competencies in the core technical skills. There is a growing need for qualified service personnel in mechatronics, rather than in pure mechanics or pure electronic control technologies (Shetty, Kondo, Campana, \& Kolk, 2002).

A well-educated high-performance workforce that possesses practical skills is difficult to assemble in today's world of rapidly changing technology, especially in the electro-mechanical and mechatronics fields. The traditional practice in enterprises globally is to provide training/retraining to their employees via conventional in-company

(C) 2018 by the authors; licensee Modestum Ltd., UK. This article is an open access article distributed under the terms and conditions of the Creative Commons Attribution License (http://creativecommons.org/licenses/by/4.0/).

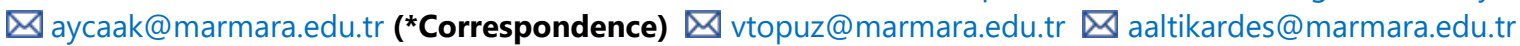




\section{Contribution of this paper to the literature}

- A model for practical training of advanced and industrial areas that requires expensive equipment using innovative remote laboratory.

- The development of educational model by content analysis for the online Mechatronics education.

- Multi-lingual special E-learning platform in the user friendly environment with Learning Management System.

training, which can be organized by themselves internally, by hired educators or, quite often, by the producers of the industrial equipment. In the European Union (EU), $38 \%$ of the companies rely on such internal training. However, a closer look shows that not all employees participate in such training owing to family responsibilities $(40 \%)$ or a conflict with their work schedule (39\%) (Ferreira \& Müller, 2004). It is clear that this training approach usually does not accommodate the individual needs of practicing engineers and technicians. Further, this approach usually does not leverage communications technology and distance learning to accommodate different learning styles.

Aside from in-company training, many other sources of continuing education are used today. Statistically, 32\% of the total population in the EU consults the Internet for self-directed learning. However, the use of the Internet to attend online courses is relatively low, reaching only $5 \%$ in this group in 2010 . Additionally, this rate is growing slower than expected, increasing by only 2 percentage points from 2007 to 2010 (Eurostat, 2013).

E-learning methods are similarly used infrequently for in-company training in the electro-mechanicalmechatronics industry. Experiments that can be conducted remotely are essential for training technicians and practicing engineers in technical professions.

In the field of mechatronics, various remote experiments and remote laboratories have been developed (Basso \& Bagni, 2004; Casini, Prattichizzo, \& Vicino, 2004; Castellanos, Hernandez, Santana, \& Rubio, 2005; Corradini, Ippoliti, Leo, \& Longhi, 2001; Gadzhanov, Nafalski, \& Nedic, 2014; Hercog, Gergic, Uran, \& Jezernik, 2007; Ko et al., 2005; Salzmann, Gillet, \& Huguenin, 2000; Sanchez, Dormido, Pastor, \& Morilla, 2004; Tan, Lee, \& Leu, 2000; Valera, Diez, Valles, \& Albertos, 2005). Most of these studies provided training in only a limited number of experiment facilities through a single set. In addition, most of these studies utilized the LabVIEW or MATLAB platform. The number of studies offering both training opportunities and experiments is very low. The study by Xu et al. (2013) is unique in that the authors introduced an Internet-based remote-controlled robot crossover project through an international cooperative program based in Japan, China, Thailand, and Taiwan.

Rojko et al. (2011) had represented the Merlab project in their study. In Merlab project the training, special Elearning platform has been built in the user-friendly environment, which is based on a combination of commercial eCampus platform and open-source Moodle platform. The sets in the Merlab project are two degrees of freedom SCARA robot and a servo motor. Rodrigiuez et al. (2015) presented hardware and software architecture for developing educational laboratories by connecting real programmable logic controllers (PLCs) to virtual industrial plants. Fernandez et al. (2015) demonstrated how using mechatronics and robotics in distance education can be a motivational tool to promote retraining for people of all ages who received minimal training during engineering.

The "E-Learning Education and Innovative Remote Laboratory for Mechatronics" project, which we call EDUMEC, was co-funded by the European Union Lifelong Learning Program called Leonardo da Vinci Transfer of Innovation Action. This project was conducted by eight project partners under the leadership of Marmara University Vocational School of Technical Sciences. The other project partners are Festo, Çizgi-Elektronik, and TEGEV from Turkey; the University of Versailles Saint-Quentin-en-Yvelines and the Universite de Technologie de Belfort-Montbeliard from France; Zavod Prava Poteza from Slovenia; and the Czech Republic VSB - the Technical University of Ostrava from the Czech Republic.

The main aim of the EDUMEC project is to introduce good practices into vocational training in mechatronics related to national and international qualifications. To realize this goal, we leveraged information and communication technologies (ICT) and established methodological as well as didactic approaches. All training materials were prepared according to levels 3, 4, 5, and 6 of the European Qualifications Framework (EQF).

The EDUMEC project is unique compared with similar studies owing to the following novel aspects:

- Multilingual Web portal (English, Turkish, Czech, Slovenian, and French),

- Innovative real-time control platform (RTCP),

- Up-to-date remotely controlled laboratory (RCL),

- Multilingual pedagogical course books for self-learning,

- The opportunity for advanced and industrial learning with three experimental sets. 


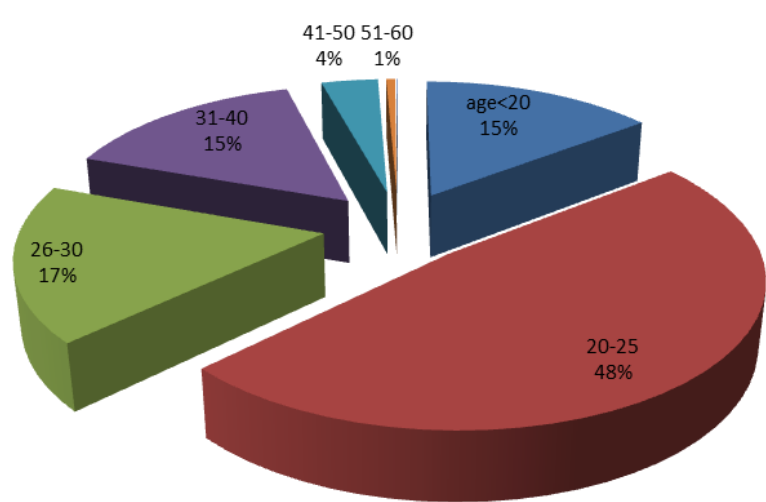

Figure 1. Age distribution of student participants

Anyone who wants to improve their technical knowledge/skills can benefit from the educational opportunities offered by this project free of cost. Membership is compulsory to participate in this project and get an appointment to perform experiments using the appointment system.

Analyses of the knowledge and skills requested by students and trainers are presented in Section II. The infrastructure of e-learning mechatronics education in the remote laboratory is shown in Section III. Section IV presents the evaluations by the students who participated in the EDUMEC program. Finally, the conclusions are given in Section $\mathrm{V}$.

\section{ANALYSIS OF THE SITUATION AND CONCEPTUAL DEVELOPMENT}

The first important part of the EDUMEC project is analyzing the situation and conceptualizing the educational approach. The analysis included situation analysis and evaluation of the pre-requirements for implementing development education in vocational education and relevance of the European labor markets, identification of stakeholders, exchange of good practices and concepts for module development and development of an emechatronics program.

In this part of the project, an analysis of needs concerning knowledge and skills as requested from industrial partners was conducted. The goal was to analyze the cognitive and formative knowledge of the target groups, analyze learning levels and explore advantages and disadvantages of the methods and content applied to the inhouse training of partners. Finally, an analysis of the needs related to education methods in in-house training was performed.

For the situation analysis and the evaluation of requirements, questionnaires were distributed to students and teachers in three countries: Turkey, France, and Slovenia. More than 1,000 students participated in the survey. Female participants constituted only $10 \%$ of the survey participants. The age distribution of the participating students is shown in Figure 1.

Almost 450 of the surveyed students had earned a Bachelor's degree. The second-most frequent educational level was vocational and high school. Nearly $70 \%$ of the survey participants had consistent employment and just over 200 participants had part-time employment or were freelancers. Most of the students who participated in the survey expressed an interest in mechatronics, IT, software engineering, electronics and robotics (Figure 2). 


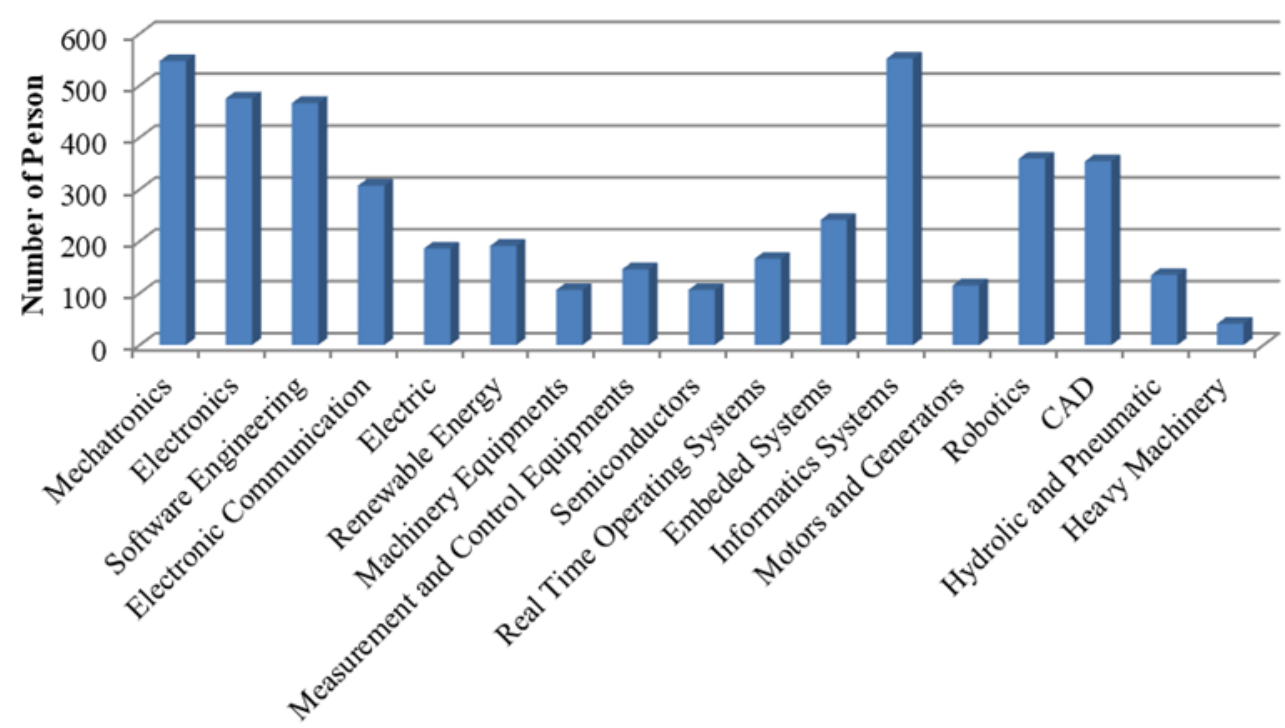

Identity of Interest

Figure 2. Interest in various fields

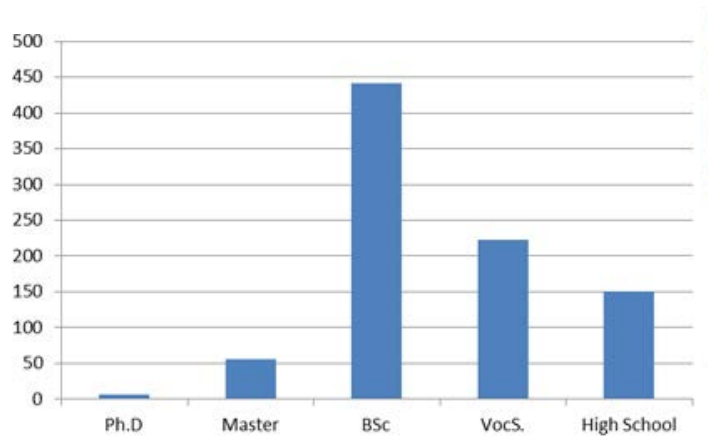

(a)

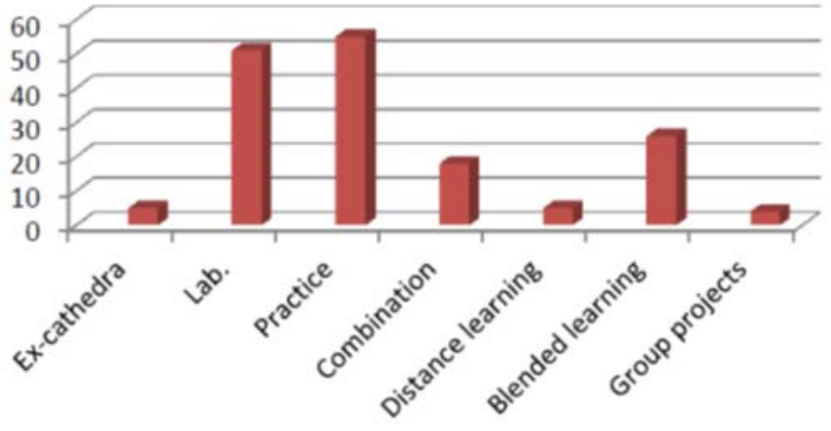

(b)

Figure 3. (a) Educational level and (b) Most commonly used learning styles in the participating organizations

More than 600 of the student participants believed that they were able to find and select information from various sources such as the Internet. Nearly $60 \%$ of the students stated that they could quickly adapt to new working methods and technologies: around $20 \%$ reported that they are good at adapting and only a minority thought their adaptation abilities were unsatisfactory. Just above $50 \%$ of the participants agreed that they are very good at multi-tasking and another $20 \%$ reported that they are good at this skill.

Nearly $65 \%$ of the student participants reported that they are very good at using hardware equipment and another $30 \%$ responded that they were good at it. More than 800 students reported that they are very good or good at using selected word-processing programs. Nearly all the participating students responded that they are good or very good at using e-mail. Only a minority of students said that they do not have skills in searching the Internet. $85 \%$ of the students said that they are active in at least one Internet forum/chat room. $96 \%$ of the students had personal computers with an Internet connection at home. Nearly half of the students had already participated in an e-learning course and most of these found it useful. $71 \%$ of the participants had already participated in informal training programs that were not part of their formal education.

More than $75 \%$ of the participants had never operated a mechatronic device through the Internet. There are various reasons for not participating in e-learning courses, including more than 520 students reporting that no such course had been organized until then; $11 \%$ said the reason was lack of time, about $5 \%$ said the training schedule did not fit their working obligations, and another $5 \%$ was not interested in such education.

In the questionnaire for educators/teachers, 183 people responded. Most of the participating organizations had over 700 students. The educational levels of these organizations are shown in Figure 3a. The most commonly used learning styles in these institutions are shown in Figure $\mathbf{3 b}$; the most frequent responses were practice, laboratory work, and blended learning. 
Table 1. Preferred Lessons

\begin{tabular}{|c|c|c|c|c|c|c|}
\hline Name of the Course & $\begin{array}{l}\text { Definitely } \\
\text { Should (5) } \\
\end{array}$ & (4) & (3) & (2) & (1) & $\begin{array}{c}\text { Definitely } \\
\text { Should Not(0) } \\
\end{array}$ \\
\hline Fundamentals of Electrical Engineering & $18 \%$ & $8 \%$ & $13 \%$ & $10 \%$ & $8 \%$ & $43 \%$ \\
\hline Fundamentals of Mechanical Engineering & $13 \%$ & $6 \%$ & $12 \%$ & $10 \%$ & $5 \%$ & $50 \%$ \\
\hline Mechatronic Systems and Devices & $30 \%$ & $15 \%$ & $11 \%$ & $6 \%$ & $8 \%$ & $33 \%$ \\
\hline Introduction to Automation & $24 \%$ & $14 \%$ & $12 \%$ & $8 \%$ & $8 \%$ & $37 \%$ \\
\hline Introduction to Robotics & $31 \%$ & $14 \%$ & $12 \%$ & $5 \%$ & $4 \%$ & $34 \%$ \\
\hline Applied Sensor Systems & $20 \%$ & $11 \%$ & $13 \%$ & $6 \%$ & $4 \%$ & $46 \%$ \\
\hline Applied Control Systems Theory & $14 \%$ & $9 \%$ & $13 \%$ & $6 \%$ & $5 \%$ & $53 \%$ \\
\hline Servo Drives & $12 \%$ & $7 \%$ & $12 \%$ & $7 \%$ & $6 \%$ & $57 \%$ \\
\hline Power Electronics & $12 \%$ & $19 \%$ & $11 \%$ & $6 \%$ & $6 \%$ & $57 \%$ \\
\hline Electrical Circuits & $16 \%$ & $12 \%$ & $11 \%$ & $8 \%$ & $4 \%$ & $49 \%$ \\
\hline Digital Systems & $22 \%$ & $13 \%$ & $11 \%$ & $5 \%$ & $3 \%$ & $46 \%$ \\
\hline Industrial Robots & $17 \%$ & $9 \%$ & $10 \%$ & $6 \%$ & $4 \%$ & $54 \%$ \\
\hline Robot Programming & $32 \%$ & $11 \%$ & $10 \%$ & $5 \%$ & $3 \%$ & $38 \%$ \\
\hline Micro Controller and Embedded Systems & $24 \%$ & $8 \%$ & $10 \%$ & $6 \%$ & $4 \%$ & $48 \%$ \\
\hline Signal and Image Processing & $16 \%$ & $10 \%$ & $11 \%$ & $7 \%$ & $4 \%$ & $52 \%$ \\
\hline Building Management Systems & $9 \%$ & $7 \%$ & $11 \%$ & $7 \%$ & $5 \%$ & $61 \%$ \\
\hline Computer Aided Measurement and Control & $21 \%$ & $8 \%$ & $11 \%$ & $8 \%$ & $4 \%$ & $43 \%$ \\
\hline Manufacturing Technology & $11 \%$ & $6 \%$ & $12 \%$ & $13 \%$ & $8 \%$ & $58 \%$ \\
\hline Materials Science & $8 \%$ & $8 \%$ & $9 \%$ & $8 \%$ & $6 \%$ & $61 \%$ \\
\hline Engineering Software & $31 \%$ & $13 \%$ & $10 \%$ & $7 \%$ & $3 \%$ & $37 \%$ \\
\hline PLC Controllers and Industrial Networks & $15 \%$ & $9 \%$ & $11 \%$ & $7 \%$ & $4 \%$ & $54 \%$ \\
\hline Artificial intelligence & $30 \%$ & $12 \%$ & $11 \%$ & $6 \%$ & $4 \%$ & $36 \%$ \\
\hline Emerging / Alternative Technologies & $33 \%$ & $12 \%$ & $10 \%$ & $4 \%$ & $2 \%$ & $39 \%$ \\
\hline
\end{tabular}

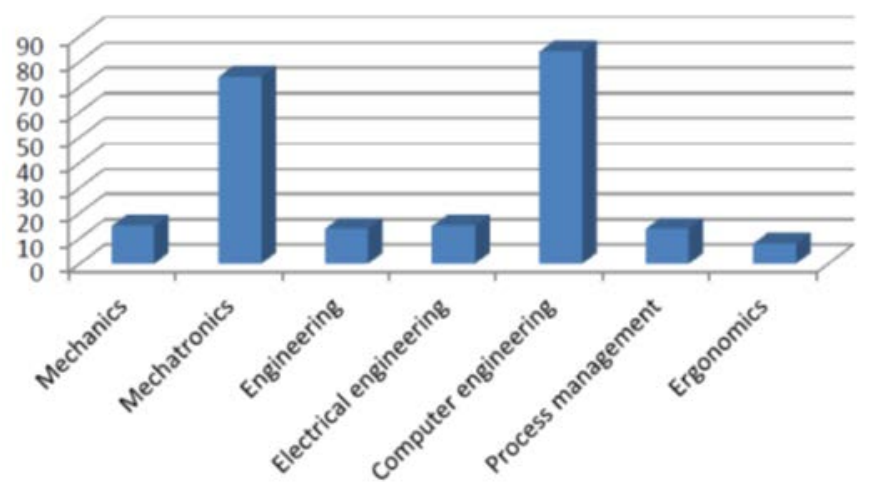

Figure 4. Areas for the planned remote laboratories

Participants were asked which course they would prefer to take for 23 lessons. They were asked to rate each option from 0 to 5 based on their preference. The students were mostly interested in the following courses: Mechatronics Systems and Devices, Introduction to Robotics, Robot Programming, Engineering Software, and Artificial Intelligence and Emerging/ Alternative Technologies (Table 1).

Nearly half of the participating organizations had no plans of adopting distance learning, and nearly $40 \%$ of them had not considered distance learning as an option. The major concerns regarding the introduction of distance learning were costs, technical possibilities, and lack of interest from students. Almost $74 \%$ of the participating organizations had planned to introduce remote laboratories into their educational process, largely in the areas of mechatronics and computer engineering (Figure 4).

Planning for remote laboratories was most common in technical vocational schools, vocational higher-education institutions, and universities (bachelor's degree level) (Figure 5). 


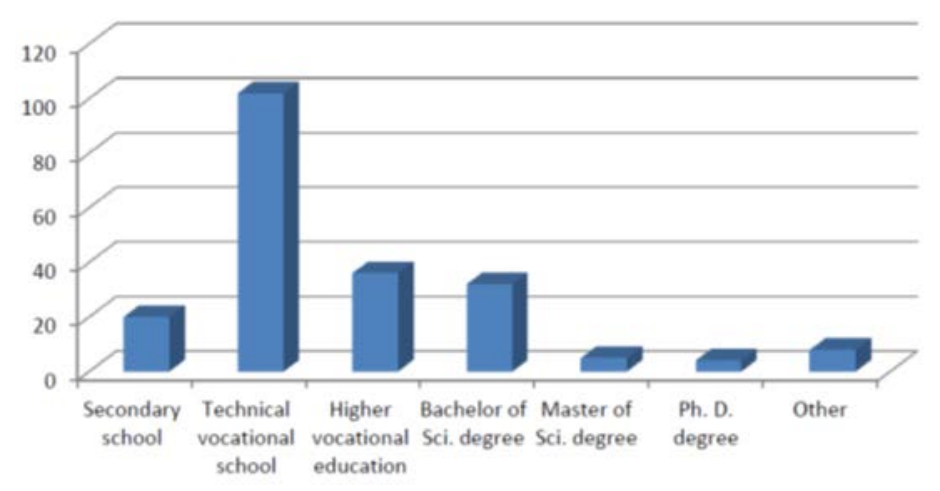

Figure 5. Educational levels for the planned remote laboratories

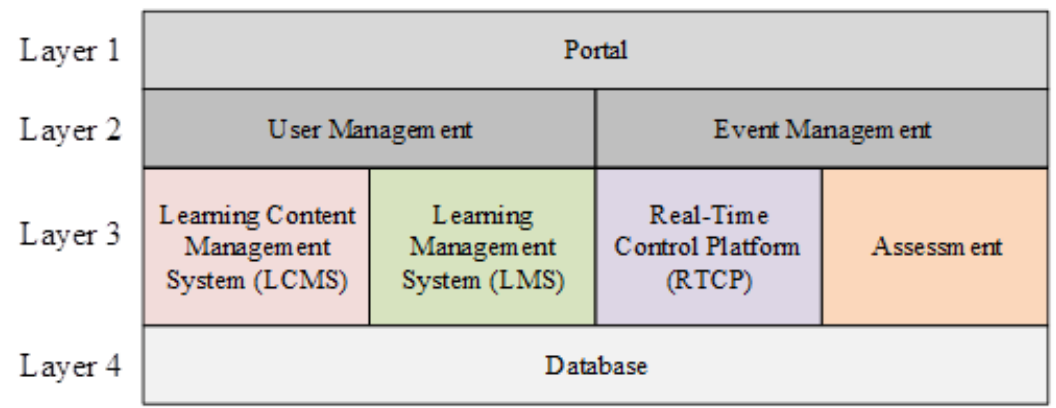

Figure 6. Training model

\section{INFRASTRUCTURE OF PROJECT}

The realized project-training model is based on the UKeU e-Learning framework (Habraken, 2008). As shown in the Figure 6 the framework is built using four layers. Each layer describes the services that perform specific tasks in a certain area of the e-Learning solution.

Layer 1: Portal - The portal provides a single port of entry for the users to the different services in the e-Learning framework and is responsible for the authentication of the users. The user can access more than fifty books, job advertisements, and announcements using this portal. List of courses is given in the Appendix. The course books were selected based on the responses to the questionnaire shown in Table 1. All the books were pedagogical selflearning-directed texts written at EQF levels 4, 5, and 6 in five different languages (English, Turkish, French, Czech, and Slovene). The homepage of the Web portal is shown in Figure 7. 


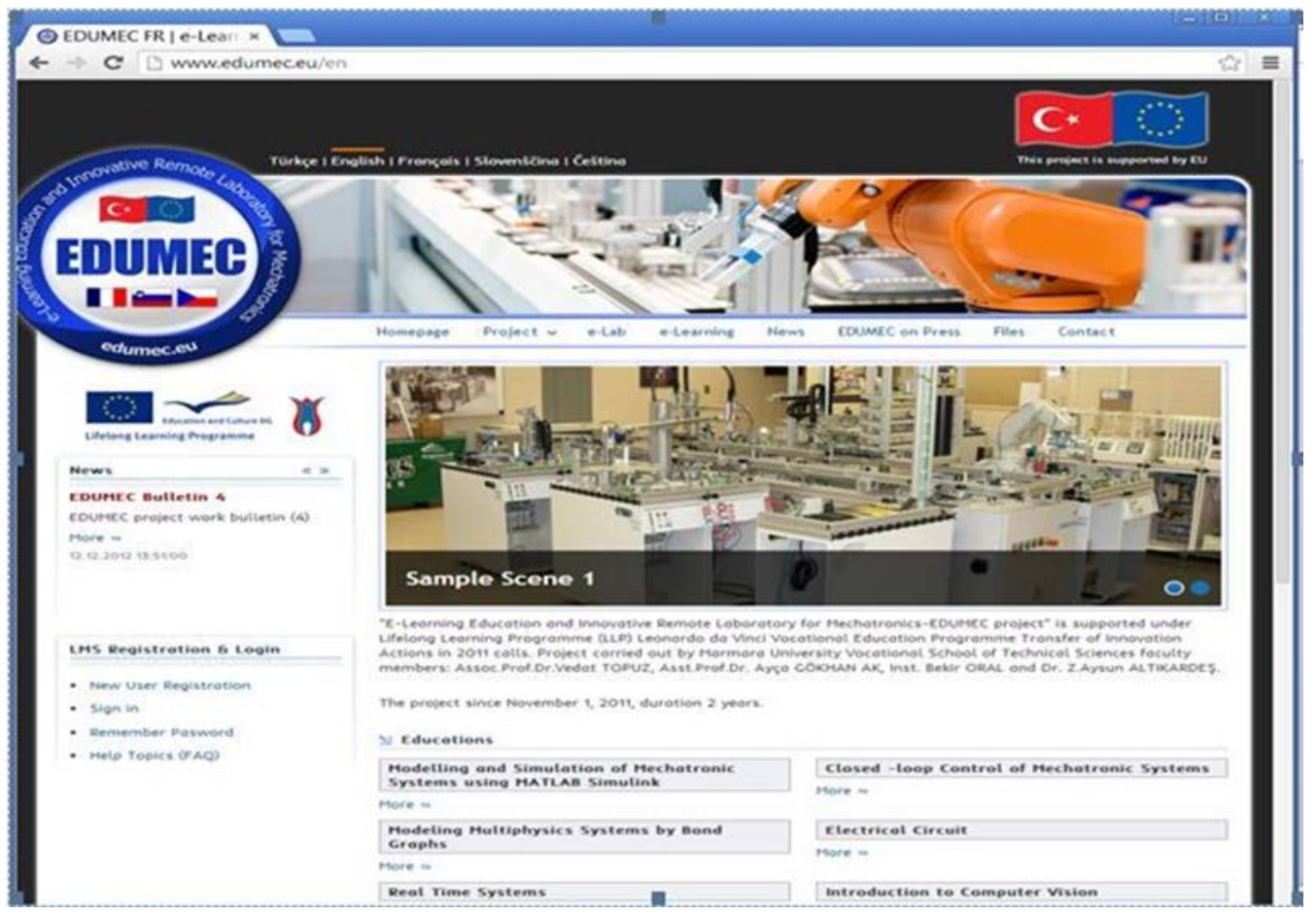

Figure 7. The homepage of the EDUMEC Web portal

Layer 2: Common Services - They do not perform any pedagogical function. While User Management service authorizes users and assigns privileges to every user, Event Management services provide scheduling and reminder functions for users.

Layer 3: Learning Services - These services provide the core functionality for e-Learning solutions. This layer determines four different services. In Learning Content Management System (LCMS) module, lectures prepared by instructors in PDF, PowerPoint or Flash format are uploaded to the system. It is also possible uploading the videos in AVI or MPEG format via this module. Learning Management System (LMS) is a service which registers users, tracks courses in the catalog, records data from learners and provides searching and reporting capabilities to users of the service. A multilingual real-time LMS has been designed and implemented to manage the Web-based asynchronous training offered. This system is based on a robust architecture that connectivity with the RTCP. The LMS logs and reports detailed data (such as date and place of attendance, courses and exams taken, scores on exams, and performed experiments) for each registered user. These reports were used to generate an "EDUMEC Certificate of Achievement" for the user.

Three different users are defined in the LMS system. These are:

a. Trainee: The trainees only attend classes, exams and practices, and make appointments for experiments.

b. Instructor: They can add lessons to the system in the course module or questions and answers to the exam pool in the exam module. In the experiment module, they can follow the experiment live and interfere with the experiment if desired.

c. Administrator: Admin can give the instructors relevant authorities; query the progress of the course attendees and observe the progress of the trainee according to the exam result. He/ she also prepare the certificate of achievement.

Assessment. Assessment System is a service which measures students' performance against specific goals. Through this module, trainees are examining over the internet. Examination dates and times can be determined by the country/teaching staff of the course. The questions of the exams are determined randomly for each trainee according to the difficulty of the questions entered into the system by instructor. When a trainee enters more than one test, he or she is faced with different questions. It is also allowed to enter an exam for one course only once in a day. The courses and durations attended by trainees are controlled via the LMS system. Trainees who do not have the minimum attendance period to the course are not allowed to enter the exam at the end of the course. The success criterion is to have participated in the courses in the specified time period and to obtain a success rate of $60 \%$ from the online examination.

Real-Time Control Platform (RTCP). In the EDUMEC project, according to the training model, experiments are conducted in real time. For this purpose, an infrastructure was constructed to enable real-time and remote 


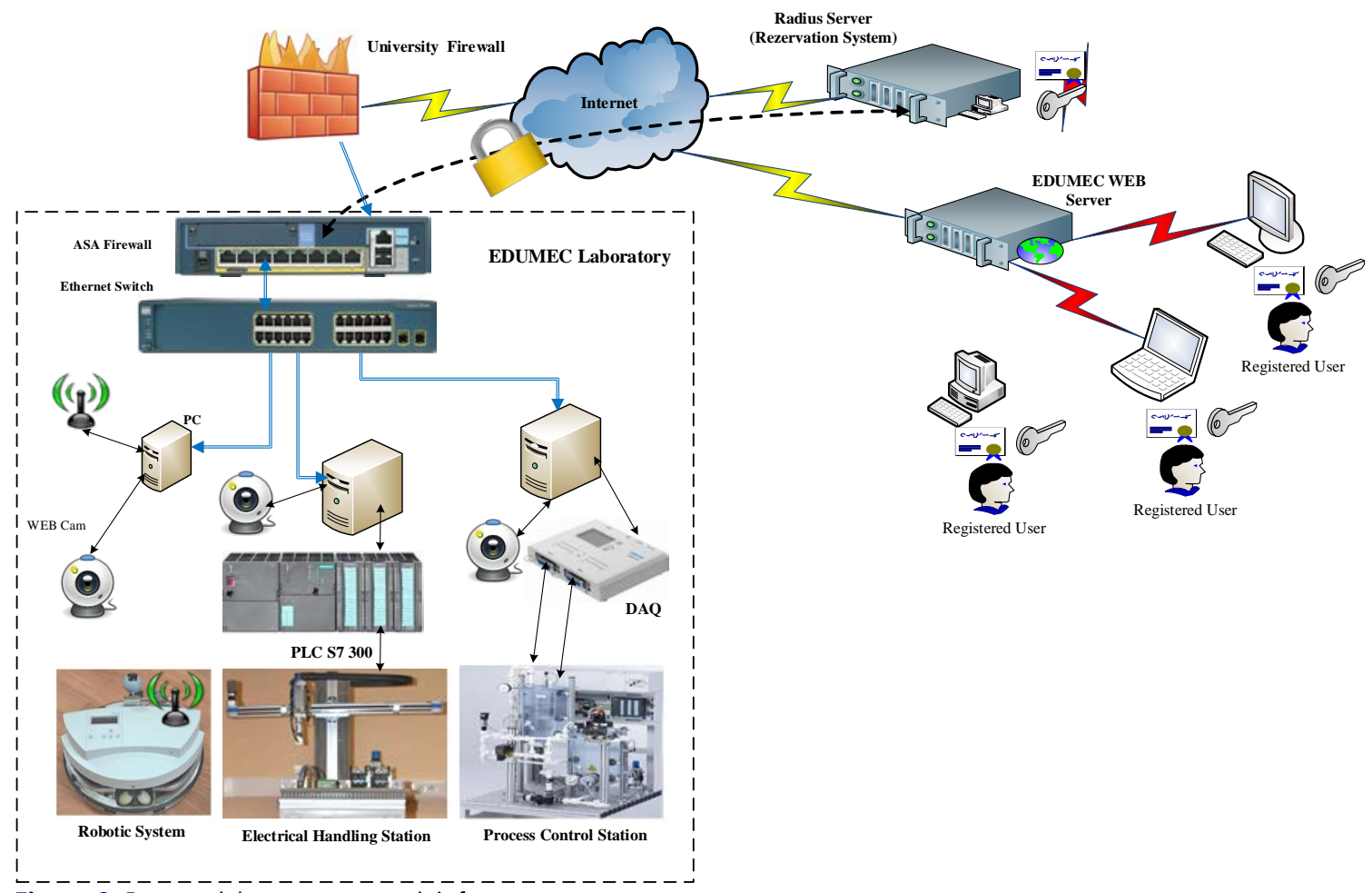

Figure 8. Remote laboratory network infrastructure

\section{e-Lab Reservation}

\begin{tabular}{|c|c|c|c|c|c|c|}
\hline \multicolumn{7}{|c|}{ Mart 2014} \\
\hline Pt & Sa & ça & $\mathrm{Pe}$ & $\mathrm{Cu}$ & ct & $\mathbf{p}_{\mathbf{z}}$ \\
\hline 24 & 25 & 26 & 27 & 28 & 1 & 2 \\
\hline 3 & 4 & 5 & 6 & 7 & 8 & 9 \\
\hline 10 & 11 & 12 & 13 & 14 & 15 & 16 \\
\hline 17 & 18 & 19 & 20 & 21 & 22 & 23 \\
\hline 24 & 25 & 26 & 27 & 28 & 29 & 30 \\
\hline 31 & 1 & 2 & 3 & 4 & 5 & 6 \\
\hline
\end{tabular}

New Reservation

Experimental Platform Lab 1: Proccess Control -

Reservation Date 31.03 .2014

Start Time 16:21

Duration of Use 01:00

Save

Server Time: 31 Mart 2014 16:20 Server Time: 31 Mart 2014

e-Lab platforms, every day on weekdays 10:30 to 16:30 serving to

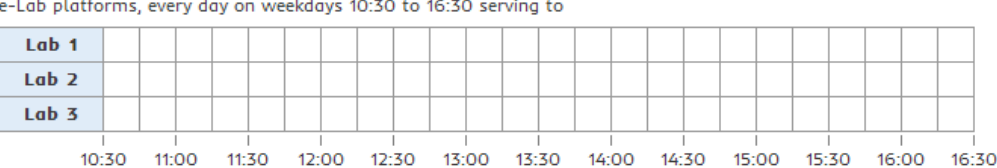

$\checkmark$ Reservations

No reservation made for today.

Figure 9. Reservation interface

experiments. The EDUMEC remote laboratory network infrastructure was based on client-server architecture; the structure is illustrated in Figure 8. In this connection, the users provide the virtual private network (VPN) connection to the system via a remote procedure call (RPC) protocol. The system provides a reservation, based on available days and time slots, to the user to enable the performance of experiments. The system security is provided by the VPN connection created by a Cisco ASA Firewall.

Three mechatronic sets have already been established in the RTCP. However, the physical infrastructure is designed to support many more experimental platforms. To use the experiment sets, users follow these steps:

1. Download and install the e-Lab VPN-Client application.

2. Make a reservation using the Web portal e-LAB reservation system. Then, the Radius server generates a unique number to maintain a VPN connection. This unique number used for remote desktop (RDP) connections using the VPN-Client application (Figure 9). 


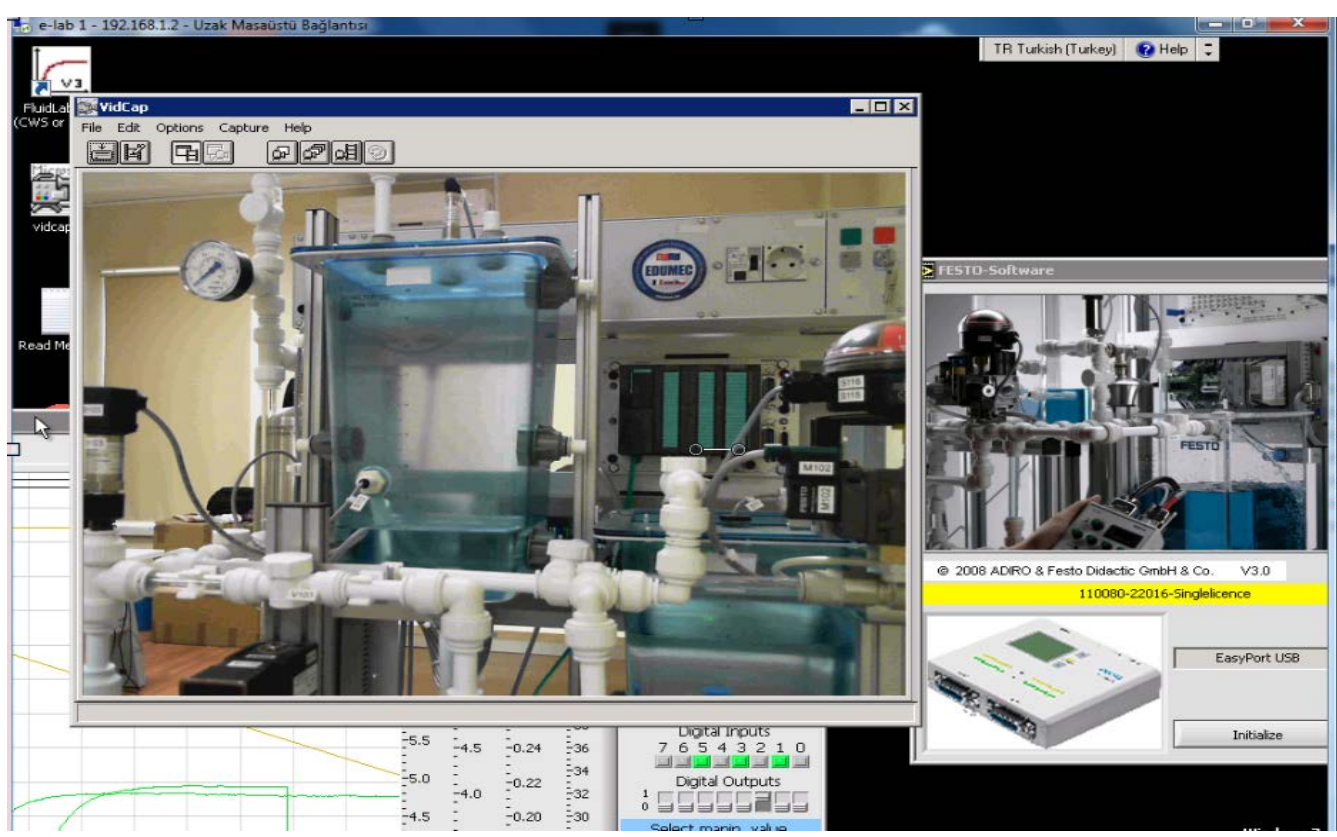

Figure 10. Remote access to the process control unit

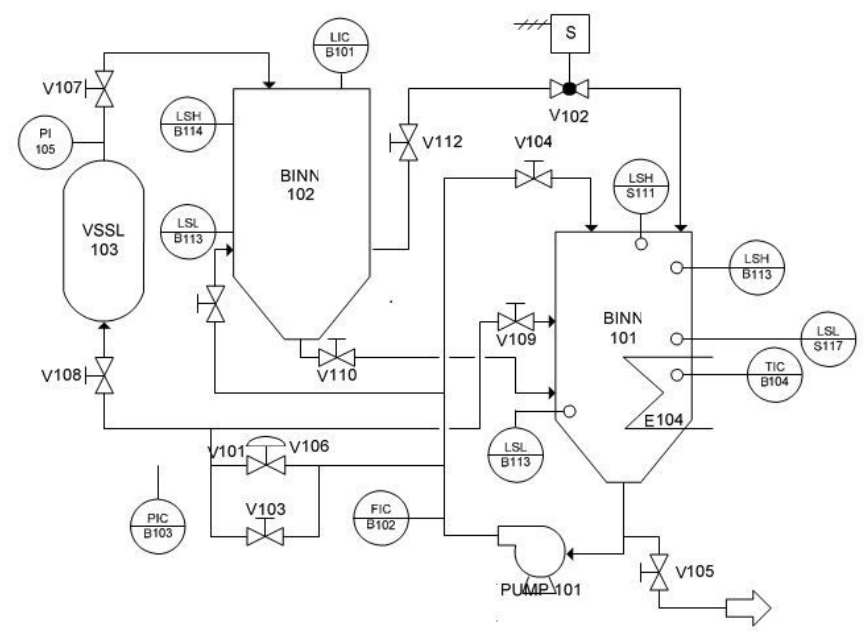

Figure 11. P\&ID diagram of the process control unit

3. At the reserved time, a VPN connection is established via the VPN-Client application, which uses an RDP in the background.

\section{Remotely Controlled Laboratory}

In this project, three experiment sets were used to form a remotely controlled mechatronic laboratory, selected based on the users' preferences given Table 1: a process control set, mobile robot, and electric and pneumatic handling system. Users can remotely conduct experiments related to different aspects of mechatronics and control areas using these training sets.

Process control set. In this set, four types of process control experiments (liquid level control, flow control, pressure control, and temperature control) can be performed via remote connections to a PLC or a computer and a data acquisition (DAQ) board. The remote system during real-time Web-based control is shown in Figure 10.

A detailed picture and PI diagram of the process control system are respectively shown in Figure 11.

The process control system consists of the following components: BINN 102 and BINN 101: Upper and lower tanks; PIC/B103: Controller: (PLC or DQA board and PC); Pump 101: Centrifugal pump; V106: Proportional valve; V 102: Two-way ball valve with pneumatic rotary drive; LIC/B101: Ultrasonic level transmitter; LSH/B114, LSL/ 
Table 2. Experiments for process control

\begin{tabular}{|c|c|}
\hline Experiment & Objectives \\
\hline Project planning & $\begin{array}{l}\text { - Draw up a PI diagrams for a controlled system. } \\
\text { - Draw an Instrument loop diagram of a controlled system. }\end{array}$ \\
\hline Analysis of the tank & - Calculation of container volume. \\
\hline Analysis of a pump & - Determining the delivery rate of a pump. \\
\hline Analysis of a proportional valve & - Determining the flow rate of a proportional valve. \\
\hline Analysis of a heating element & - Operation of a heating element. \\
\hline Analysis of an ultrasound sensor & - Recording the characteristic of an ultrasound sensor. \\
\hline Analysis of a flow meter & - Recording the characteristic of a flow meter. \\
\hline Analysis of a pressure sensor & - Recording the characteristic of a pressure sensor. \\
\hline Analysis of a temperature sensor & - Recording the characteristic of a temperature sensor. \\
\hline Commissioning a level-controlled system & - Determining the operating range and operating point of a controlled system. \\
\hline Commissioning a flow controlled-system & - Determining the operating range and operating point of a controlled system. \\
\hline $\begin{array}{l}\text { Commissioning a pressure-controlled } \\
\text { system }\end{array}$ & - Determining the operating range and operating point of a controlled system. \\
\hline $\begin{array}{l}\text { Commissioning a temperature-controlled } \\
\text { system }\end{array}$ & - Determining the operating range and operating point of a controlled system. \\
\hline Identification of a controlled system. & $\begin{array}{l}\text { - } \text { Determining the time response of a controlled system. } \\
\text { - } \quad \text { Determining operation of a controlled system with P controller. } \\
\text { - } \quad \text { Determining operation of a controlled system with a PI controller. } \\
\text { - } \quad \text { Determining operation of a controlled system with a PD controller. } \\
\text { - } \quad \text { Controller setting using the Ziegler-Nichols method. }\end{array}$ \\
\hline
\end{tabular}

B113, and LSH/B113: Capacitive proximity switches; VSSL 103: Pressure control tank; PI 105: Pressure transmitter; FIC/B102: Flow transmitter; E104: Heating element; and TIC/B104: Thermistor.

The tank level control system is a closed-loop control system equipped with a reservoir tank and a pump motor subsystem. Based on the assumption that the system is either linear or linearized, the differential equation of this system can be obtained as follows:

$$
C d h=\left(q_{i}-q_{o}\right) d t
$$

where $C$ is the capacitance of the tank $\left(\mathrm{m}^{2}\right), h$ is the tank liquid level $(\mathrm{m})$, and $q_{i}$ and $q_{0}$ are the tank inlet and outlet flow rates, respectively $\left(\mathrm{m}^{3} / \mathrm{sec}\right)$. Thus (Macancela \& Canizares, 2014),

$$
G p(s)=\frac{H(s)}{Q i(s)}=\frac{0.02544}{s+0.005697}
$$

The experiments designed to teach users about process control are given in Table 2.

The main purpose of the experiment set is to teach the following skills to the user:

- Working on different process control systems (i.e., liquid level, flow, pressure, and temperature). These processes can be operated individually or as batch processes using manual valves on the set.

- Understanding the process control P\&ID diagrams. The system can be diagnosed by following the P\&ID diagrams.

- Modeling the behavior of the system. The experimental set allows experiments on all input-output models in the system. Thus, the relationship between the mathematical model and the input-output models can be analyzed.

- Understanding the working principles of different sensors and actuators. There are several types of sensors (pressure, ultrasonic, proximity, and temperature) as well as electrical and pneumatic actuators.

- Controlling the system using a classic ON/OFF or PID controller. Parameters of the controllers can be determined easily using a computer. Thus, the effects of parameter changes on the system performance can be examined.

Mobile Robot. The mobile robot has an embedded PC controller (an I/009 control board with an FPGA) and a microcontroller connected via an Ethernet interface (Figure 12). The mobile robot has nine distance sensors, two optical sensors, two proximity sensors, and a camera. Additional features can be included in the structure using the electrical input and output ports. 


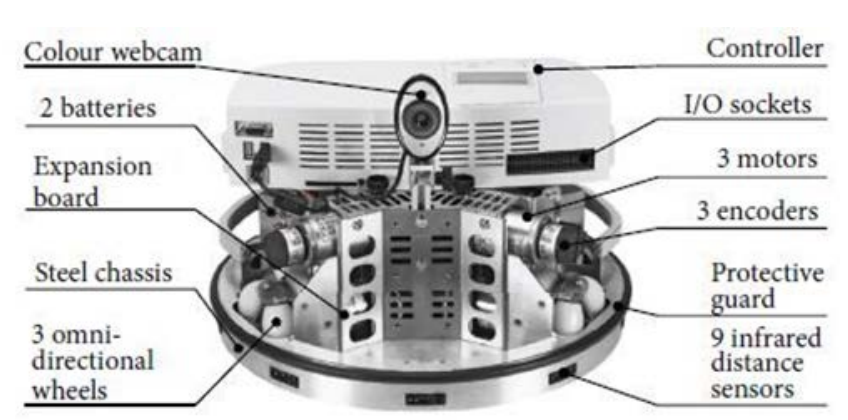

Figure 12. Mobile robot (photo from Robotino manual (Bliesener et al., 2007)

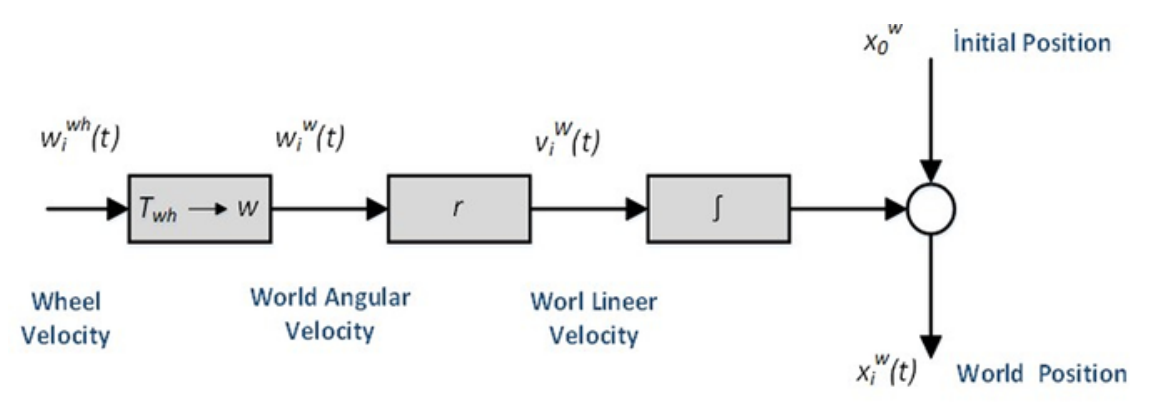

Figure 13. Kinematic model of the mobile robot

The mobile robot uses three engines developed for the Omnidrive drive units. The three drive units allow for motion in all directions-forward, backward, and sideways-and the robot can also turn within its own diameter. Figure 13 shows the kinematic model of the robot.

The kinematic model of the robotino is:

$$
\left[\begin{array}{l}
w_{1}(t) \\
w_{2}(t) \\
w_{3}(t)
\end{array}\right]=\frac{1}{r} \cdot\left[\begin{array}{l}
v_{1}(t) \\
v_{2}(t) \\
v_{3}(t)
\end{array}\right]=\frac{1}{r} \cdot\left[\begin{array}{lll}
-\sin \left(\emptyset_{1}\right) & \cos \left(\emptyset_{1}\right) & R \\
-\sin \left(\emptyset_{2}\right) & \cos \left(\emptyset_{2}\right) & R \\
-\sin \left(\emptyset_{3}\right) & \cos \left(\emptyset_{3}\right) & R
\end{array}\right] \cdot\left[\begin{array}{c}
\dot{x}_{r}(t) \\
\dot{y}_{r}(t) \\
\Omega(t)
\end{array}\right]
$$

Here $w_{i}$ is the angular velocity of each individual wheel, $v_{i}$ is the translational velocity of each individual wheel, $r$ is the wheel radius, $R$ is the distance from the center of the robot to the center of wheel, $x_{r}$ and $y_{r}$ characterize the robot coordinate system, $\Omega$ is the tangential rotational velocity of the robot, and $\varphi_{i}$ describes the rotation of the wheel shaft relative to the robot coordinate system equation:

The robot velocity can be determined from the wheel velocities by inverting the above matrix. Equation (3.4) can be simplified by replacing the transformation matrix from the wheel velocities to the world angular velocity with the matrix $T_{w h \rightarrow w}$. The world velocity of the robot can be determined from the measurements of the angular velocities of the three wheels by inverting the matrix $T_{w h \rightarrow w}$. Thus, the estimated position after moving the robot from time $t_{0}$ to time $t_{1}$ is determined using the following equation:

$$
\left[\begin{array}{c}
x_{w}\left(t_{1}\right) \\
y_{w}\left(t_{1}\right) \\
\theta\left(t_{1}\right)
\end{array}\right]=\left[\begin{array}{c}
x_{w, 0} \\
y_{w, 0} \\
\theta_{0}
\end{array}\right]+r \cdot \int_{t_{0}}^{t_{1}}\left[T_{w h \rightarrow w}\right]^{-1}\left[\begin{array}{l}
w_{1}(t) \\
w_{2}(t) \\
w_{3}(t)
\end{array}\right] d t
$$

where $x_{w}\left(t_{1}\right)$ and $y_{w}\left(t_{1}\right)$ are the coordinates in the world coordinate system at time moment $t_{1}, \theta\left(t_{1}\right)$ is the orientation angle at time $t_{1}, x_{w, 0}$ and $y_{w, 0}$ are coordinates in the world coordinate system at time $t_{0}$, and $\theta_{0}$ is the orientation angle at time $t_{0}$ (Oltean, Dulău, \& Puskas, 2010).

The mobile robot can be programmed with Robotino View software installed on a computer that is accessed via a wireless LAN connection. Because the mobile robot has its own Linux operating system, the user can directly control the omnidrives using Telnet connections. The wheel units have an angle degree of 120 between each other. Robotino View can transmit signals to the motor controller in addition to displaying, changing, and evaluate sensor values. The mobile robot can even be programmed during actual operation via Robotino View (Figure 14). 


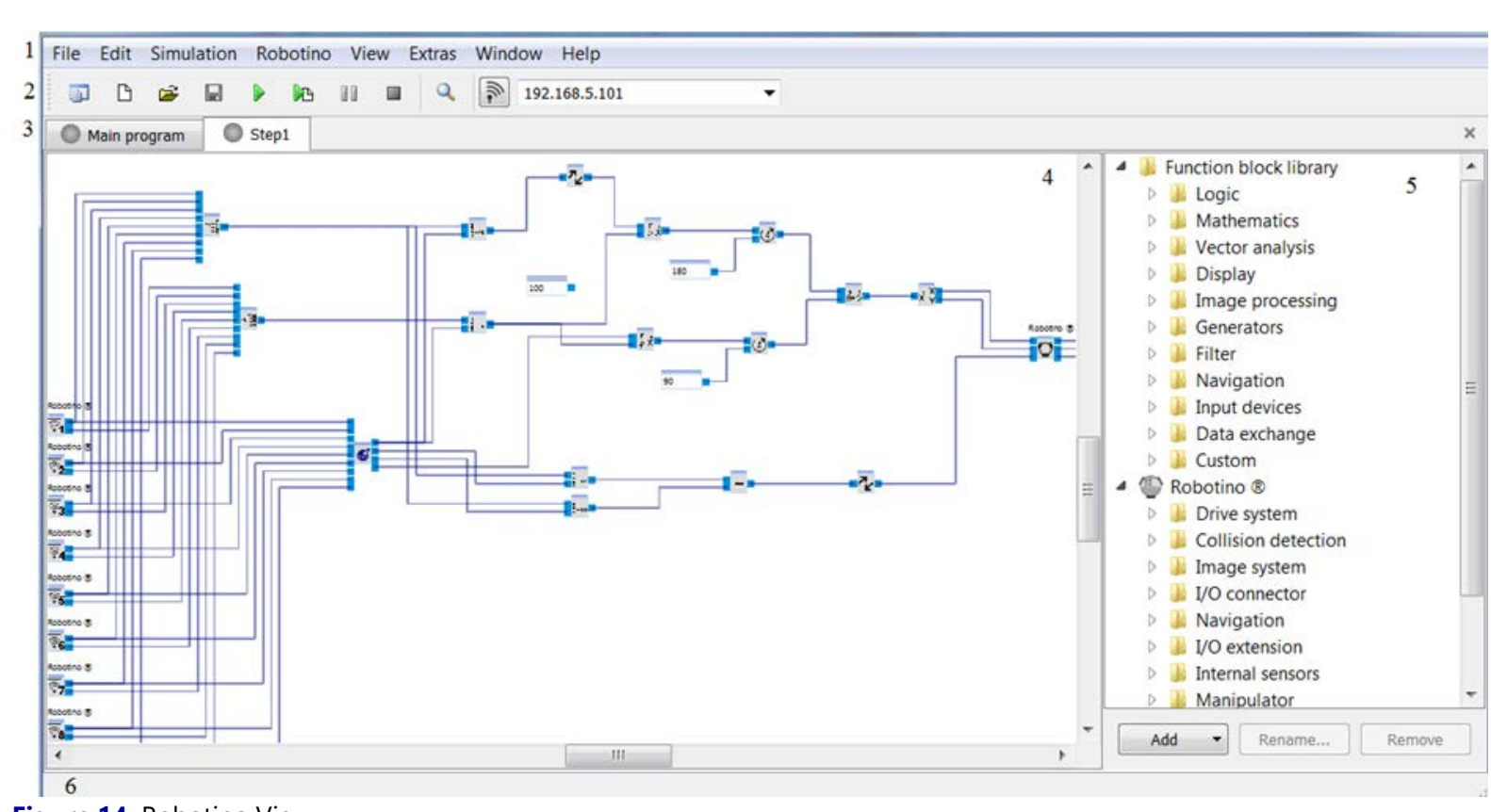

Figure 14. Robotino View

Table 3. Experiments for robot control

\begin{tabular}{|c|c|}
\hline Experiment & Objectives \\
\hline Analysis of Mobile Robot & $\begin{array}{l}\text { - Electrical motor control learning the mechanical construction of a mobile } \\
\text { robot system. }\end{array}$ \\
\hline $\begin{array}{l}\text { Remote control and programming of the mobile } \\
\text { robot }\end{array}$ & $\begin{array}{l}\text { - Learning remote control and basic functions of graphical programming } \\
\text { software }\end{array}$ \\
\hline Linear running of mobile robot in any direction & $\begin{array}{l}\text { - Commissioning of a mechatronic system } \\
\text { - Learning electrical motor control }\end{array}$ \\
\hline Omnidrive & - Learning electrical motor control/drive unit \\
\hline Acquisition and scaling of sensor data & Learning collision protection \\
\hline Search and approach & - Learning closed-loop control of a mechatronic system \\
\hline Line follows & - Graphics programming applications for a mobile robot system \\
\hline Wall follow, search and approach, color tracking & - Analysis of sensor data for various applications \\
\hline
\end{tabular}

In the Robotino View interface, 1 is the menu bar that contains menus to perform actions such as load/save, edit, view. 2 is the tool bar containing quickly accessible buttons to perform some of the functions from the menus, buttons to start and stop the simulation, an input box for Robotino IP address, and a connect button. In the program selector section (3), the user can switch between the main program and the subprograms of a project. The subprogram "Step1" is visible in Figure 13. 4 is the program workspace, where the program is viewed and edited. The library of function blocks available for programming is labeled 5. The status bar (6) shows information about the project and the application status.

After learning the basic principles of the mobile robot, the experimental stage can commence. A list of experiments starting from simple tasks and extending to complex applications is shown in Table 3. However, the applications that can be developed with the mobile robot are not limited to this list; after the experimental stage, the user may develop further applications.

Electrical and Pneumatic Handling Station. Material flow is a sub-function of the handling station. Additional sub-functions are conveying and storing. Users who access the computer remotely via a VPN can run the PLC software using Simatic Manager through a multi-point interface (MPI) adapter. The electrical handling station is equipped with a flexible two-axis handling device. The inserted workpieces are detected in the retaining device by an optical reflex light sensor.

The electrical handling device fetches the workpieces from the retaining device with the help of a pneumatic gripper that is fitted with an optical sensor. The sensor differentiates between "black" and "non-black" workpieces. The workpieces can be deposited on different slides based on these criteria. The electrical handling station comprises a receptacle module, a PicAlfa module, a slide module, a profile plate, a trolley, a control console, and a PLC board (Figure 15). 


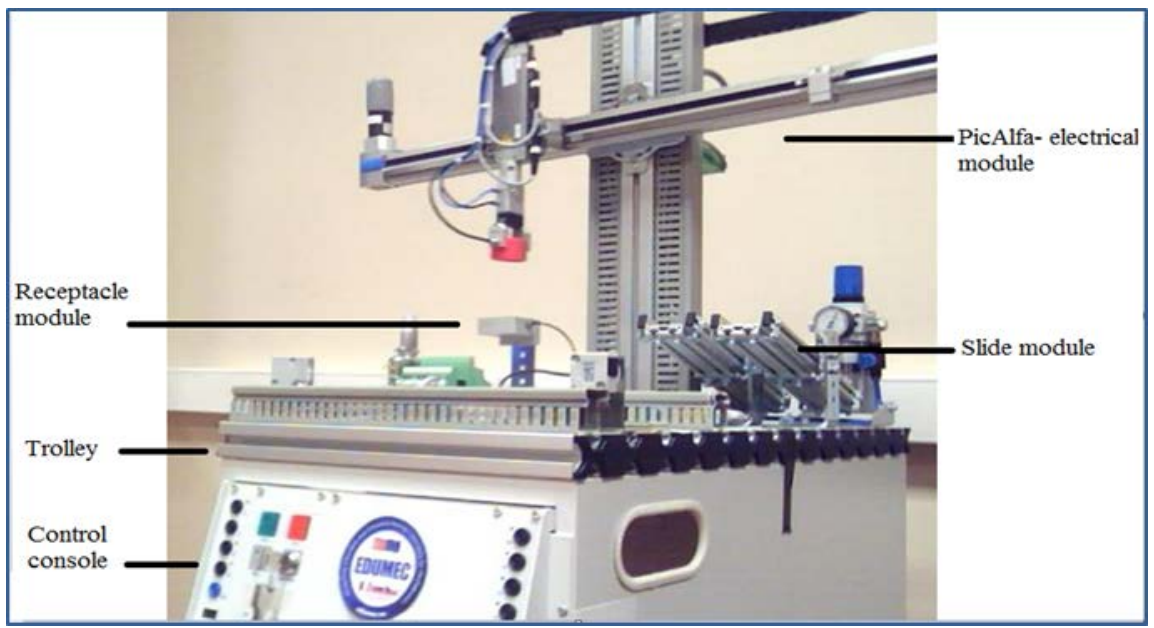

Figure 15. Electrical handling station

Table 4. Experiments for electrical handling station

\begin{tabular}{|c|c|}
\hline Experiment & Objective \\
\hline \multirow{4}{*}{ System activations } & - Understanding fully by analyzing the scheme of Electrical Handling Station \\
\hline & - Learning fundamentals of Programmable Logic Circuit using S7- 300 \\
\hline & $\begin{array}{l}\text { - Learning the connection of electrical handling station to the computer by using } \\
\text { PLC-S7 PC-adapter with USB/MPI converter. }\end{array}$ \\
\hline & - To control start and stop activities. \\
\hline \multirow{2}{*}{ Separating of the different components } & - To make an error detection \\
\hline & - To perform emergency stop system. \\
\hline
\end{tabular}

The electrical and pneumatic handling station is designed to improve the user's PLC programming knowledge. Users can create a scenario using electrical or pneumatic actuators according to the signals coming from different sensors and switches. Experiments built on the electrical and pneumatic handling station are listed in Table 4.

A connection is made between the test set and the computer via a PLC-S7 PC adapter with a USB/MPI converter by clicking on the monitor on/off button in the toolbar. OB1 is the main organization module. The process orders of the other programs and data modules are assigned in this main module. In emergencies, such as an electrical short, loss of Internet connection, and other faults, the emergency stop module is activated and the entire system stops. In the case of an emergency stop the emergency stop program block is called which resets the operating panel outputs and station outputs.

\section{Evaluation of the System}

A total of 41 persons participated to the pilot training for the EDUMEC project and 25 persons successfully completed it. Pilot training was attended by Computer, Electrical, Electronics and Mechatronics students at EQF level 3, 4 and 5, which were our target group. $23 \%$ of these students participated in the survey that done to analyze the conceptual and formative knowledge of the target groups in the first stage of the study. Certificates of achievement through the EDUMEC project were given to them at the end of the training.

A questionnaire including 23 questions was prepared to evaluate the participants' opinions about the adequacy, quality, efficiency, understandability, accessibility, and benefits of the pilot training.

The evaluation criteria and the results for three different experiment sets are shown in Table 5 (values are expressed as percentages of users responding). The pilot training received positive approval from around $65 \%$ of the participants, showing that the mechatronics field is very difficult to study for beginners. 
Table 5. The results in percentage for three different experiment sets

\begin{tabular}{|c|c|c|c|c|c|}
\hline & 1. Disagree & 2. & 3. & 4. & $\begin{array}{l}\text { 5. Completely } \\
\text { Agree }\end{array}$ \\
\hline \multicolumn{6}{|c|}{ The contents of the training correspond to the training goals } \\
\hline Process Control & $6.45 \%$ & $0.00 \%$ & $0.00 \%$ & $12.90 \%$ & $80.65 \%$ \\
\hline Robotic & $16.67 \%$ & $3.33 \%$ & $0.00 \%$ & $3.33 \%$ & $76.67 \%$ \\
\hline PLC and motion control & $7.50 \%$ & $2.50 \%$ & $2.50 \%$ & $10.00 \%$ & $77.50 \%$ \\
\hline \multicolumn{6}{|l|}{ Exercises are adequate } \\
\hline Process Control & $6.45 \%$ & $3.23 \%$ & $6.45 \%$ & $16.13 \%$ & $67.74 \%$ \\
\hline Robotic & $13.79 \%$ & $6.90 \%$ & $6.90 \%$ & $6.90 \%$ & $65.52 \%$ \\
\hline PLC and motion control & $7.50 \%$ & $2.50 \%$ & $12.50 \%$ & $5.00 \%$ & $72.50 \%$ \\
\hline \multicolumn{6}{|l|}{ E-test are adequate } \\
\hline Process Control & $12.50 \%$ & $6.25 \%$ & $3.13 \%$ & $9.38 \%$ & $68.75 \%$ \\
\hline Robotic & $13.33 \%$ & $3.33 \%$ & $0.00 \%$ & $13.33 \%$ & $70.00 \%$ \\
\hline PLC and motion control & $5.26 \%$ & $5.26 \%$ & $2.63 \%$ & $5.26 \%$ & $81.58 \%$ \\
\hline \multicolumn{6}{|c|}{ I estimate the whole e-learning contents as excellent } \\
\hline Process Control & $9.68 \%$ & $3.23 \%$ & $9.68 \%$ & $25.81 \%$ & $51.61 \%$ \\
\hline Robotic & $16.67 \%$ & $0.00 \%$ & $10.00 \%$ & $20.00 \%$ & $53.33 \%$ \\
\hline PLC and motion control & $12.50 \%$ & $0.00 \%$ & $12.50 \%$ & $10.00 \%$ & $65.00 \%$ \\
\hline
\end{tabular}

Table 6. Questionnaire Results for Learning Portal

\begin{tabular}{|c|c|c|c|c|c|}
\hline & 1. Disagree & 2. & 3. & 4. & $\begin{array}{l}\text { 5. Completely } \\
\text { Agree }\end{array}$ \\
\hline Learning portal is well organised & $7.89 \%$ & $2.63 \%$ & $10.53 \%$ & $18.42 \%$ & $60.53 \%$ \\
\hline $\begin{array}{l}\text { The learning time is close to the predicted } \\
\text { learning time. }\end{array}$ & $15.79 \%$ & $0.00 \%$ & $5.26 \%$ & $13.16 \%$ & $65.79 \%$ \\
\hline $\begin{array}{l}\text { I appreciate that I can learn anytime and from } \\
\text { any location }\end{array}$ & $7.89 \%$ & $2.63 \%$ & $5.26 \%$ & $2.63 \%$ & $81.58 \%$ \\
\hline $\begin{array}{l}\text { I think that gained knowledge will be useful in } \\
\text { my future career. }\end{array}$ & $15.79 \%$ & $0.00 \%$ & $2.63 \%$ & $15.79 \%$ & $65.79 \%$ \\
\hline I would participate in the advanced training & $21.05 \%$ & $2.63 \%$ & $5.26 \%$ & $15.79 \%$ & $55.26 \%$ \\
\hline \multirow[t]{2}{*}{$\begin{array}{l}\text { I have (or will) recommend the training to my } \\
\text { friends. }\end{array}$} & $15.79 \%$ & $2.63 \%$ & $7.89 \%$ & $10.53 \%$ & $63.16 \%$ \\
\hline & $\begin{array}{l}\text { Distance } \\
\text { Learning }\end{array}$ & $\begin{array}{c}\text { Educational } \\
\text { Booklet }\end{array}$ & $\begin{array}{l}\text { Free of } \\
\text { Access }\end{array}$ & Experiments & Everything \\
\hline $\begin{array}{l}\text { Which aspects of training and materials did } \\
\text { you like the most. }\end{array}$ & $60.47 \%$ & $11.63 \%$ & $4.65 \%$ & $9.30 \%$ & $13.95 \%$ \\
\hline
\end{tabular}

Finally, in this project, the possibility of successfully completing experiments performed by remote control was proven (Table 6). The results demonstrate the success and quality of the EDUMEC Project educational materials, pilot training, and mechatronics remote laboratory infrastructure.

\section{CONCLUSIONS}

Remote access to a laboratory in the field of mechatronics, which was previously limited in availability, has now been established through the EDUMEC project at Marmara University. Access to the EDUMEC laboratory is available globally, allowing users to conduct real-time mechatronics experiments. On the EDUMEC platform, a remote access laboratory and 50 different courses are made available in an asynchronous format.

The effectiveness of the designed education model was primarily tested through pilot training with a set of students. Certificates of achievement were given to the students who successfully completed their training. After the pilot phase of training, the platform was opened through the EDUMEC webpage to offer asynchronous education free of charge for five years in the interest of ensuring the project's continuity. Hence, the project has accomplished its goals successfully.

At the beginning of the project, the efficiency of the system is only questionnaire questioned. The system will be updated with this questionnaire during the sustainability phase of the project. In addition, after the system has been applied for at least 2 years, feedback will be received from course trainees and employers.

Practical training in areas that require expensive equipment such as mechatronics can be performed using remote-access devices as an effective solution to provide this training. While EDUMEC offered users an option to take 50 theoretical courses in the field of mechatronics at EQF levels 3, 4, 5, and 6, they also had opportunities to 
apply some of the learned skills such as robot control, process modeling, controller design, and PLC programming, in real time.

The EDUMEC project represented a successful example of a project in this area. Future work in improving the EDUMEC project in cooperation with the Turkey Ministry of Education will aim to expand the project to reach more institutions and people.

\section{REFERENCES}

Basso, M., \& Bagni, G. (2004). Artist: A Real-Time Interactive Simulink-Based Telelab. Proc. IEEE International Symposium on Computer-Aided Control System Design, pp. 196-201. https://doi.org/10.1109/CACSD.2004.1393875

Bliesener, M., Weber, C., Kling, K., Karras, U., \& Zitzmann, D. (2007). Festo Robotino Manual. Denkendorf, Germany: Festo Didactic GmbH \& Co. KG.

Casini, M., Prattichizzo, D., \& Vicino, A. (2004). The automatic control telelab-a web-based technology for distance learning. IEEE Control System Magazine, 24(3), 36-44. https:/ / doi.org/10.1109/MCS.2004.1299531

Castellanos, A. R. S., Hernandez, L., Santana, I., \& Rubio, E. (2005). Platform for Distance Development of Complex Automatic Control Strategies Using Matlab. International Journal of Engineering Education, 21(5), 790-797.

Corradini, M. L., Ippoliti, G., Leo, T., \& Longhi, S. (2001). An Internet Based Laboratory for Control Education. In: Proc. IEEE Conference on Decision and Control, pp. 2833-2838. https:/ / doi.org/10.1109/CDC.2001.980703

EUROSTAT, Education and Training, Statistical Data. (2013, March 19). Retrieved from http:/ / epp.eurostat.ec.europa.eu/portal/page/portal/education/data/database

Fernandez, G. C., Borrego, R. C., Merino, P. P., Lopez, M. A. S. C., Ruiz, E. S., Gil, M. C., \& Perez, F. M. (2015). Mechatronics and Robotics as Motivational Tools in Remote Laboratories. IEEE Global Engineering Education Conference, pp. 118-123. https:/ / doi.org/10.1109/EDUCON.2015.7095960

Ferreira, J. M., \& Müller, D. (2004). The MARVEL EU project: A Social Constructivist Approach to Remote Experimentation. 1st Remote Engineering and Virtual Instrumentation International Symposium, Villach, Austria.

Gadzhanov, S. D., Nafalski, A., \& Nedic, Z. (2014). LabVIEW Based Remote Laboratory for Advanced Motion Control. 11th International Conference on Remote Engineering and Virtual Instrumentation, pp. 129-136. https:/ / doi.org/10.1109/REV.2014.6784237

Habraken, J. (2008). Reference Architecture for e-Learning Solutions (Master Thesis). Open University, Faculty of Computer Science.

Hercog, D., Gergic, B., Uran, S., \& Jezernik, K. (2007). A DSP-Based Remote Control Laboratory. IEEE Transactions on Industrial Electronics, 54(6), 3057-3068. https:/ / doi.org/10.1109/TIE.2007.907009

Ko, C. C., Chen, B. M., Chen, J. P., Zhang, J., \& Tan, K. C. (2005). A Web-Based Laboratory on Control of a TwoDegrees-Of-Freedom Helicopter. International Journal of Engineering Education, 21(6) 1017-1030.

Macancela, A. H. I., \& Canizares, C. M. P. (2014). Construccion de Una Platadorma de Instrumentacion Virtual Sobre Labview (Master Thesis). Universidad Politecnica Salesiana Sede Cuenca.

Oltean, S. E., Dulău, M., \& Puskas, R. (2010). Position Control of Robotino Mobile Robot Using Fuzzy Logic. Automation Quality and Testing Robotics (AQTR), IEEE International Conference on, Volume: 1. https://doi.org/10.1109/AQTR.2010.5520855

Rodriguez, F., Castilla, M. D. M., Sanchez, J. A., Pawlowski, A., \& Moreno, J. C. (2015). Architecture to Develop Semi-Virtual Industrial Laboratories for the Interactive Learning of Process Automation. Computer Application Engineering Education, 24(3), 335-346. https:/ / doi.org/10.1002/cae.21709

Rojko A., Hercog D. \& Jezernik K. (2011). E-Training in Mechatronics Using Innovative Remote Laboratory. Elsevier Mathematics and Computers in Simulation, 82, 508-516. https:/ / doi.org/10.1016/j.matcom.2010.10.017

Salzmann, C., Gillet, D., \& Huguenin, P. (2000). Introduction to Real-Time Control Using Labview With An Application To Distance Learning. International Journal of Engineering Education, 16(3), 255-272.

Sanchez, J., Dormido, S., Pastor, R., \& Morilla, F. (2004). A Java/Matlab-Based Environment for Remote Control System Laboratories: Illustrated with an Inverted Pendulum. IEEE Transactions on Education, 47(3), 321-329. https://doi.org/10.1109/TE.2004.825525

Shetty, D., Kondo, J., Campana, C., \& Kolk, R.A. (2002). Real-Time Mechatronic Design Process for Research and Education. Proceedings ASEE Annual Conference.

Tan, K. K., Lee, T. H., \& Leu, F. M. (2000). Development of a Distant Laboratory Using Labview. International Journal of Engineering Education, 16(3), 273-282. 
Valera, A., Diez, J. L., Valles, M., \& Albertos, P. (2005). Virtual and Remote Control Laboratory Development. IEEE Control System Magazine, 25(1), 35-39. https:/ / doi.org/10.1109/MCS.2005.1388798

Welp, E. G., Labenda, P., \& Jansen, S. (2006). Teaching Theory and Practice in Mechatronics Engineering. International Design Conference - Design Dubrovnik - Croatia.

Xu, C., Ming, A., Kanamori, C., Aoyama, H., Li, H., Xu, L., .. Wong, C.-C. (2013). Internet-Based Crossover Robot Remote Control Competition among Asian Countries. Elsevier Mechatronics, 23(8), 933-941. https://doi.org/10.1016/j.mechatronics.2013.06.003

\section{APPENDIX}

\section{List of Courses}

\begin{tabular}{|c|c|c|c|c|}
\hline English & Turkish & Czech & Slovenian & French \\
\hline $\begin{array}{l}\text { Modelling and } \\
\text { Simulation of } \\
\text { Mechatronic Systems } \\
\text { using MATLAB } \\
\text { Simulink }\end{array}$ & & & $\begin{array}{l}\text { Modeliranje in } \\
\text { simulacije mehatronskih } \\
\text { sistemov z uporabo } \\
\text { MATLAB-Simulink }\end{array}$ & \\
\hline Digital Electronic & Sayısal Elektronik & Digitální elektronika & Digitálne elektronické & Digital Électronique \\
\hline $\begin{array}{l}\text { Closed -loop Control of } \\
\text { Mechatronic Systems }\end{array}$ & $\begin{array}{l}\text { Mekatronik sistemlerin } \\
\text { Kapalı Devre Kontrolü }\end{array}$ & & & \\
\hline $\begin{array}{l}\text { Modeling Multiphysics } \\
\text { Systems by Bond } \\
\text { Graphs }\end{array}$ & & $\begin{array}{l}\text { Modelování } \\
\text { Multifyzikálních } \\
\text { Systémů Pomocí Bond } \\
\text { Grafů }\end{array}$ & & \\
\hline Electrical Circuits & Elektrik Devreleri & Elektrické Obvody & Električna vezja & Circuits électrique \\
\hline Real Time System & & Systém Reálného času & & \\
\hline \multicolumn{5}{|l|}{$\begin{array}{l}\text { Introduction to } \\
\text { Computer Vision }\end{array}$} \\
\hline $\begin{array}{l}\text { Computer Vision / } \\
\text { image Processing / } \\
\text { Image Analysis }\end{array}$ & & & & $\begin{array}{l}\text { Introduction au Cours } \\
\text { de Traitement d'Images }\end{array}$ \\
\hline $\begin{array}{l}\text { Introduction to Robotic } \\
\text { Vision }\end{array}$ & & & & $\begin{array}{l}\text { Introduction à la Vision } \\
\text { pour la Robotique }\end{array}$ \\
\hline $\begin{array}{l}\text { Introduction to } \\
\text { Mechatronics }\end{array}$ & $\begin{array}{l}\text { Mekatronik sistemlere } \\
\text { Giriş }\end{array}$ & $\begin{array}{l}\text { Servomotor v } \\
\text { mechatronice }\end{array}$ & Uvod v mehatroniko & $\begin{array}{l}\text { Introduction à la } \\
\text { mécatronique }\end{array}$ \\
\hline Mechatronic Devices & Mekatronik Cihazlar & Mechatronická zařízení & Mehatronske naprave & $\begin{array}{l}\text { Appareils } \\
\text { mécatroniques }\end{array}$ \\
\hline $\begin{array}{l}\text { Servomotor in } \\
\text { Mechatronics }\end{array}$ & & & $\begin{array}{l}\text { Servomotor v } \\
\text { mehatroniki }\end{array}$ & \\
\hline Artificial Intelligence & Yapay Zekâ & & Umetna Inteligenca & Intelligence artificielle \\
\hline $\begin{array}{l}\text { Introduction to Process } \\
\text { Control and Sensors }\end{array}$ & $\begin{array}{l}\text { Proses Kontrole Giriş ve } \\
\text { Algılayıcılar }\end{array}$ & & & \\
\hline $\begin{array}{l}\text { Process automation } \\
\text { MPS® PA Compact } \\
\text { Workstation Manual }\end{array}$ & $\begin{array}{l}\text { MPS® PA Proses } \\
\text { Kontrol Eğitim Seti }\end{array}$ & & & \\
\hline Robotics & Robot Bilim & Robotika & robotické & Robotique \\
\hline $\begin{array}{l}\text { Basic Experiments for } \\
\text { ROBOTINO }\end{array}$ & $\begin{array}{l}\text { ROBOTINO Temel } \\
\text { Deneyler }\end{array}$ & & & \\
\hline
\end{tabular}

\section{http://www.ejmste.com}

